\title{
The Possibility of Developing Existing Residential Buldings by Installing Photovoltaic Modules Case Study: Libya - Zuwarah
}

\author{
Marim M. A. Baka and Demet Irkli Eryildiz
}

\begin{abstract}
Libya is completely dependent on non-renewable energy sources (oil and natural gas that increase the problem of global warming) to meet its needs for electric energy. After its decline in its oil production and the destruction of some power stations, especially after 2011, the electricity sector in Libya witnessed a very significant decline, as it could not meet the needs of citizens in all sectors, including the residential sector.

On the other hand, Libya has good solar radiation, as the average solar radiation at the horizontal level is $7.1 \mathrm{~kW} / \mathrm{m}^{2}$ in the coastal areas and $8.1 \mathrm{kilowatt} /$ square meters in the southern regions for nine hours per day, and the estimated amount of solar energy available annually is $3.5 \times 109$ gig watt hours, which makes it one of the countries that can use solar energy to help meet the increasing demand for electrical energy, and together, this energy is not utilized sufficiently.

This work aims to study the possibility of developing existing residential buildings by installing photovoltaic modules the photovoltaic modules have been integrated with existing buildings in Zuwarah city in different ways: on the building roof to perform functional role and facades for aesthetic role. After studying the existing residential buildings in the city, two samples were chosen as case studies to apply the integration of photovoltaic units to them using Sketch Up software, and the PV Syst software, to design the PV system.

The study clarified the role that photovoltaic systems play in the sustainable architectural formation through their ability to achieve its rules and principles, and the possibility of developing existing residential buildings in Libya - Zuwara by integrating PV with it. As well as its contribution to solving the electricity crisis in Libya.
\end{abstract}

Index Terms - Photovoltaic systems, Solar energy in Libya Zuwarah, Developing existing residential buildings in Libya Zuwarah, Environmental and economic feasibility of solar systems in Libya, Pv syst program.

\section{INTRODUCTION}

The continuous increasing in energy consumption has led to a phenomenon called Global Warming, which is expressed as a change in the global climate caused by human activity, which in turn prompted globally to search for solutions through the development of Various technologies aims to reduce energy consumption globally and to search for alternatives to generate energy that do not produce $\mathrm{CO}_{2}$ gas.

Active Solar Architecture Which about using solar radiation to generate electrical energy in buildings using

Submitted on March 31, 2021

Published on May 31, 2021.

Marim M. A. Baka, Department of Architecture, Okan University, Turkey. (e-mail: belybeke1990@gmail.com) photovoltaic systems, which considering a trend in modern architecture. Photovoltaic energy is a renewable resource inexhaustible, nor polluting the environment. In addition, the amount of all stored fossil energies is equal to only the amount of solar radiation located on Earth within three days, for example the solar energy in one minute can save the energy consumed in the world for a year [1]. Therefore, the world has increased its trend towards this energy.

The integration of solar systems into architecture is considering primary challenge for many architects, since this integration with environment is a manifestation of development; and these new concepts influenced particularly the architects thinking way and globally the architecture science [2]

The solar energy systems have many models, one of them is converting buildings from the traditional energyconsuming to energy-saving, beside the architect's ability to make the solar modules as architectural element has an impact on the exterior of the building in terms of aesthetic and functional value.

This paper is based on a study of the possibility and places of integration of PV with existing residential buildings in Libya - Zuwarah.

\section{CASE STUdY ZUWARAH CITY}

Zuwarah, known as Tamort in the Berber language, the city established in the second century BC when it was known as Kasas. Formed from the Zawagha tribe, mentioned by the Greek traveler Herodotus (420 BC), and it is likely that the word Zawagha is derived from the same origin of the word Amazigh, and they mean the free honorable ones [3]. According to urban planning in Zuwarah, it is located in the far west of the Libyan coast with total area about 5355.6541 hectares (personal interview with urban planning manager in Zuwarah). The city geographical location between 32 degrees north, and longitude 12 degrees east. It is on the border with Tunisia, about $120 \mathrm{~km}$ from Tripoli [4]. The population in 2019 according to personal interview with the responsible officer in the Civil Status Authority in Zuwarah is 42,546 people. Fig. 1 shows the location of the city.

The city is flat and slightly steep [5], with the elevation of the city center 10 meters above sea level and the lowest drop of 1 meter below sea level (Google earth pro).

Demet Irkli Eryildiz, Department of Architecture, Okan University, Turkey (e-mail: demeteryildiz ${ }^{@}$ gmail.com) 


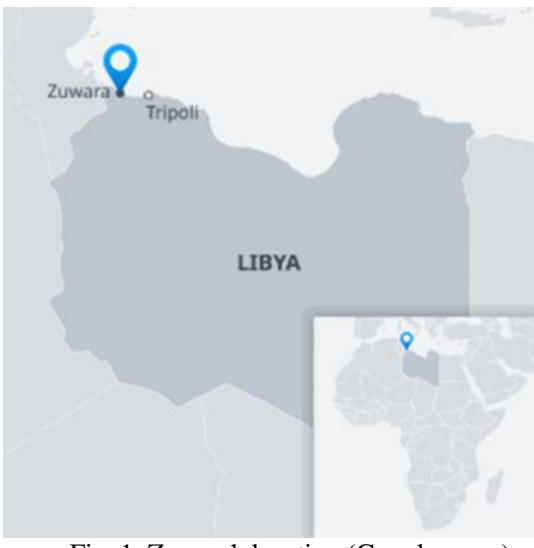

Fig. 1. Zuwarah location (Google maps).

The geographical location of the city on the Mediterranean Sea effects its climate, which classified as semi-arid climate hot and dry in summer, warm and rainy in winter [6].

In addition, the marshes cause very high humidity exceeding $75 \%$ in July and $69.3 \%$ in February. The highest rate of rainfall reaches $250 \mathrm{~mm}$ [7].

\section{SOLAR RADIATION IN ZUWARAH}

Solar radiation is the main source of atmospheric heat, and its change is the difference between one place and another in the abundance of solar energy [8]. Libya enjoys a large amount of solar radiation compared to other countries around the world.

The Libyan coast (including Zuwarah city) that lies between latitudes 32-28 have a high solar range, while the amount of solar radiation ranges between $1800-2100 \mathrm{kWh} / \mathrm{m}^{2}$ per year [9]. Annual basis average sunny hours in Zuwarah ranges from 8 to 9 hours a day and the radiation amount 7.6kilowatt $\mathrm{h} / \mathrm{m}$ in the summer, and 3.3 in kilowatt $\mathrm{h} / \mathrm{m}$ the winter. The following table shows monthly basis average sunny hours in Zuwarah since 1989 until 2010 [8].

TABLE I: MONTHLY BASIS AVERAGE SUNNy HOURS IN ZUWARAH [8]

\begin{tabular}{ccccc}
\hline & summer & spring & winter & fall \\
\hline Season rate & 10.3 & 8.0 & 6.5 & 7.7 \\
\hline
\end{tabular}

\section{ELECTRICITY IN ZUWARAH}

Zuwarah's electricity consumption is $35 \mathrm{MW}$ in summer and $20 \mathrm{MW}$ in winter. As the public electricity grid is unable to meet demand, due to the rapid population growth, lack of development in power stations, theft of electricity from the public grid, and the destruction of some power stations and transmission lines because of the war; the electricity deficit increased and reached $10 \mathrm{MW}$ in Zuwarah. there is an average power outage of 3-4 hours per day, which could increase in the summer and reach around 16 hours or more per day in August [10].

\section{SOLAR ENERGY IN ZUWARAH}

As mentioned earlier, Zuwarah has huge source of renewable energies, while the amount of solar radiation ranges between $1800-2100 \mathrm{kWh}$ and $\mathrm{m}^{2}$ per year, which is not utilized.
Through the field study conducted by the researcher. Previously, there were no attempts to use solar energy until 2019 , when the project to use solar panels for road lighting began using 500 flashes, as it appears in each one Fig. 2 includes 20 lithium-ion batteries that fully charged after 4 hours exposed to solar radiation, providing light for 27 continuous hours. The solar panel designed from the mono crystalline, considering the shade on the board and the accumulated dust and dust on it, the installation of the PV was at a fixed angle of 32 degrees facing south, and LED lamp is used. Working automatically the module reduces the intensity of lighting in the winter after one hour at night by $75 \%$, and $50 \%$ an hour before sunrise to reduce battery discharge. As the equipment directly imported from the factory in China, the cost of each module (plate, flash, and base) was 400 Libyan dinars without shipping charges.

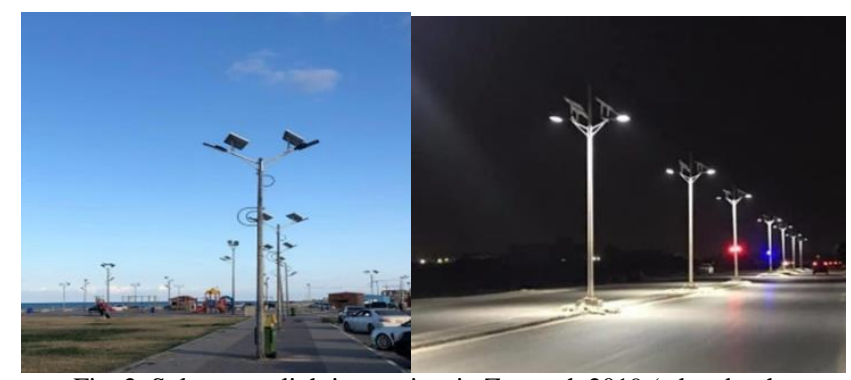

Fig. 2. Solar street lighting project in Zuwarah 2019 (taken by the researcher).

The project faced many obstacles, including:

- Lack of people acceptance of using solar panels.

- Failure to provide adequate financial support.

- The distances between units are random.

On the other hand, there are advantages to the project, including:

- The project cost is economically.

- The cost of solar lighting poles is almost equal to the cost of traditional poles, considering the infrastructure costs.

- No needs for digging or filling and cable infrastructure.

- The LED lights lifetime is double than traditional one, and consumes 8 times less electricity, without infrared rays.

- Reduce the load on the electricity grid and ensure continues street lighting.

\section{RESIDENTIAL BUILDINGS IN ZUWARAH}

The shelter is the place where the person settles for stability, comfort, spends most of his time, the origin of socialization and the place of establishing family relations [11].

Housing in Libya went through different stages in terms of shape, size and building materials, according to the economic and social developments in the country. According to the Urban plane of the city the planned area of residential buildings is about $11000 \mathrm{~km}^{2}$ of the total area of the city (personal interview with urban planning manager in Zuwarah). It can be said the residential building development in Zuwarah went through three different stages. 


\section{A. The Traditional Residential Buildings (before the Oil Discovery)}

Group of residential houses located in the Old City has an architectural style close to the antique [10]. The following figure shows the city plan in 1911 [4].

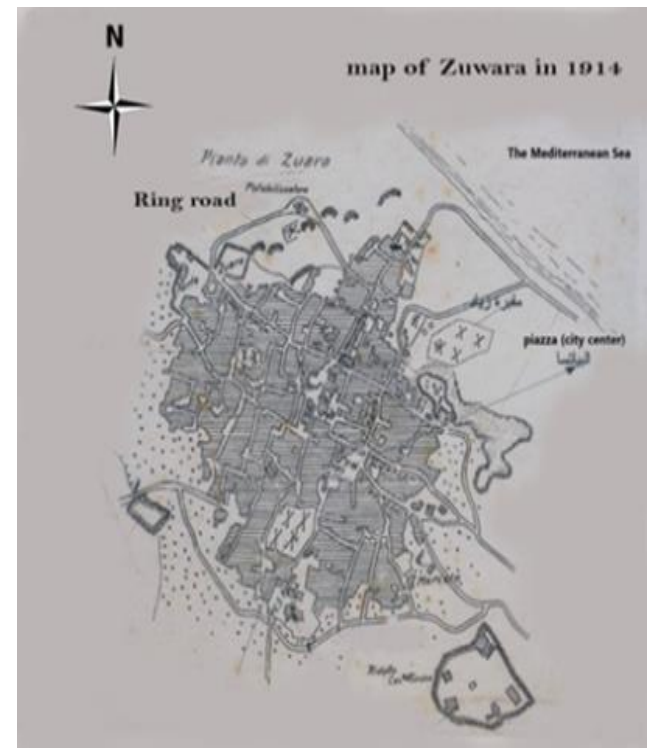

Fig. 3. Zuwarah' plan in 1911 [4].

Residential buildings at this stage so-called (Housh), characterized by simplicity and meet minimum requirements. Local materials available in nature were used in building them like gypsum stone. The roofs are built from a mixture of palm trunks and mud, as Iron was scarce and used only when necessary [4].

The building's design was also different, having a long frontage perpendicular to the street in the city, with the street being narrow to direct the wind in the required direction and to provide shade [12].

There is a rectangular courtyard in the center of the house, usually about $(4 \times 6$ meters) with rooms surrounding it, which keeps the atmosphere warm in winter due to getting solar radiation, and in summer provides shade to cool the indoor area, and reduces humidity, so the house design adapted to the local climate situation [4].

With the development of urbanization in the city, the houses design changed and the courtyard, which was the basis of the design was dispensed, the following Fig. 4-6 describes the design.

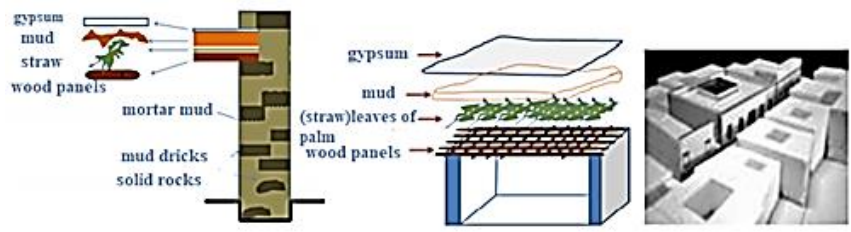

Fig. 4. Methods of traditional housing in Zuwarah [12].

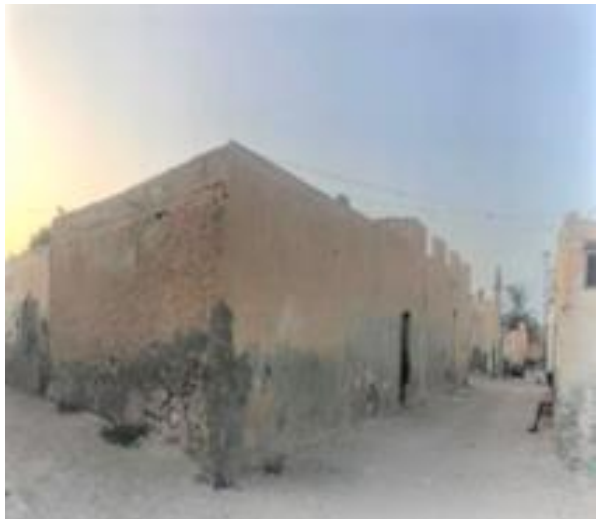

Fig. 5. The traditional building pattern (taken by the researcher).

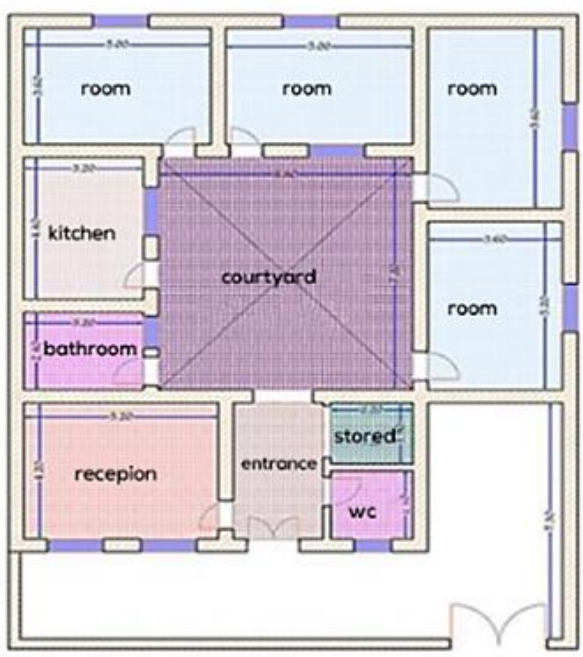

Fig. 6. Design of old houses.

B. The Traditional Residential Buildings through the Oil Discovery

This stage accompanied with the economic and social change that began to appear in Libya with the independence. In the fall of $1965 \mathrm{AD}$, the Aero Exploration Company carried out aerial photography, and in March 1966 AD, the first field survey was carried out by the Architectural Planning Company Ltd. (APB) Copenhagen, Denmark, where it prepared a comprehensive plan for the city [4].

At this stage, new building materials appeared such as cement and iron for reinforcement, which were more expensive than local materials; other than the change in room numbers and size, there was no change in the house design. In general, residential buildings have preserved their characters at this stage, as the following Fig. 7 shows.

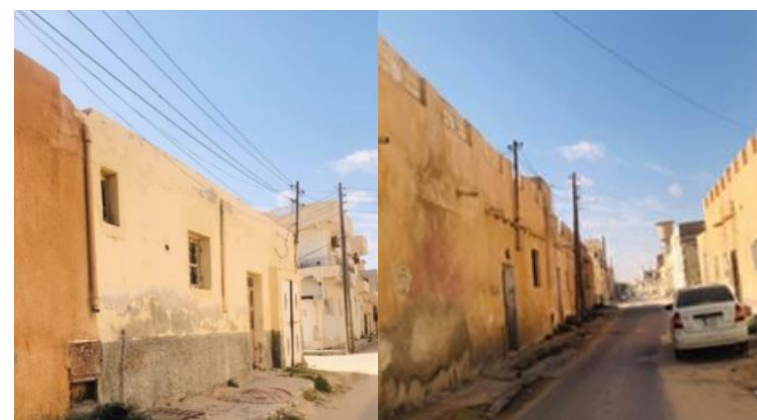

Fig. 7. Houses built in the Eighties (taken by the researcher).

As for the per capita consumption of electricity at this stage, it did not exceed $420 \mathrm{~kW}$ hours / year [10], due to the 
low standard of living of individuals in general, and the high price of electricity [13].

The buildings of this stage were distributed in a circular motion around the old residential buildings, as the 1980 Polservice' survey shows Fig. 8:

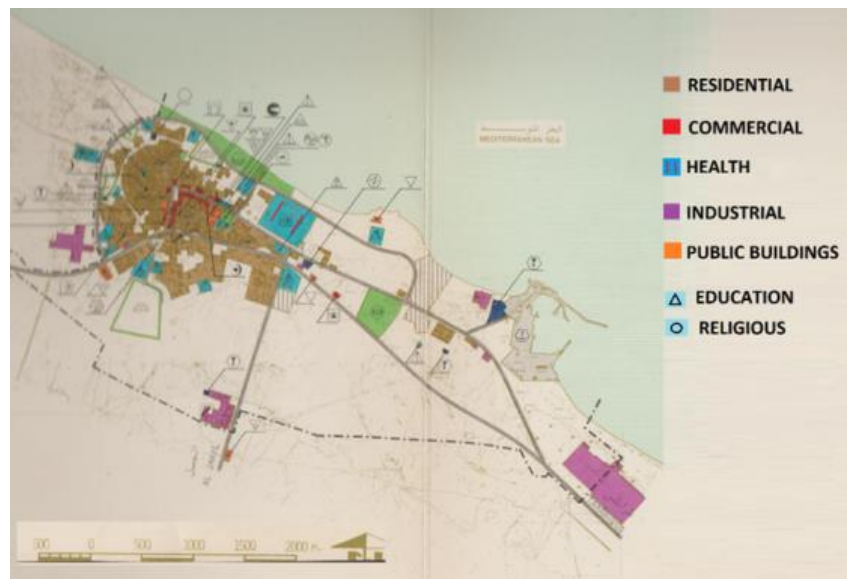

Fig. 8. 1980 Polservice' survey for Zuwarah [4].

\section{Residential Buildings with Increased Oil Revenues}

In 1980 the engineering consulting firm, Polservice, developed a comprehensive plan for the city under the name "Zuwara Sub Plans Regional Plan-2000 Final Report Report N-4", as shown in the following Fig. 9 [10].

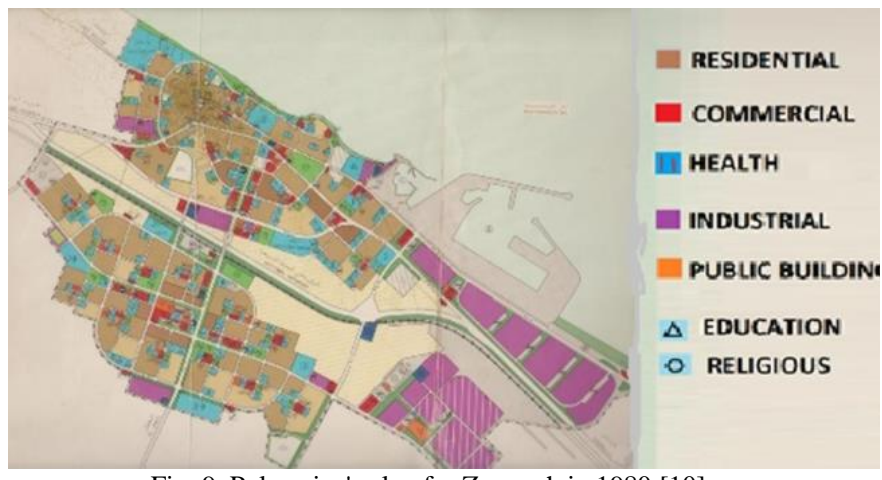

Fig. 9. Polservice's plan for Zuwarah in 1980 [10]

The plan included 3,600 housing units on an area of 110 hectares, from the previous two stages in addition to onestorey, two-story buildings with four apartments and residential buildings from 3 to 4 floors [10].

This stage related to the cultural and economic changes that have greatly affected the concept of residential buildings, as the shapes and functions of the spaces have changed, with the emergence of some new spaces such as the dining room and separate bedrooms for individuals, on the other hand, other areas such as the inner courtyard have disappeared. The shape of the buildings became open on the outside after being closed inwards. It has also become almost totally dependent on new building materials (iron, reinforced concrete, and cement bricks) [14].

At this stage, the demand for electricity in the residential sector increased as a result of the increase in the number of housing and the rise in the standard of living with the increase in oil revenues [13]. Where new electrical appliances had been used such air conditioners, washing machines, water pumps. The design of the building and electricity consuming moved away from the traditional pattern until reaching the current style.

At this stage, the city expanded greatly, and government housing projects appeared, including residential units with two floors and more, while most of the designers and implementers were foreign companies. The following Fig. 10 shows the general design of the building at this stage.

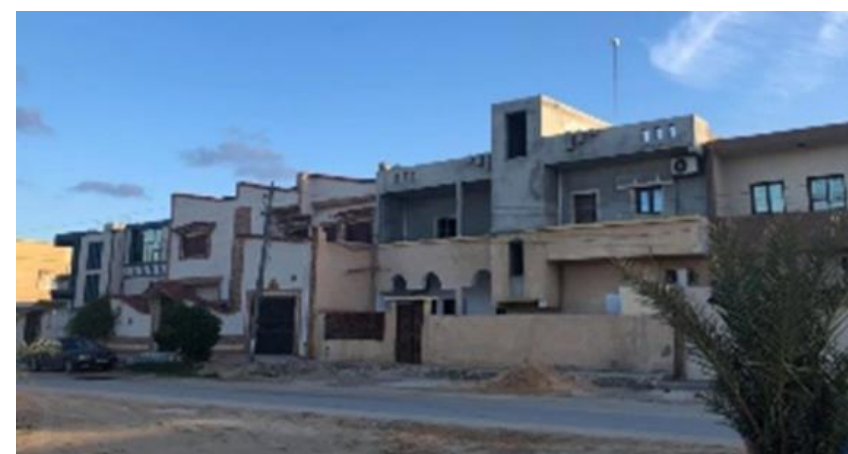

Fig. 10. Residential buildings design after 1980 (taken by the researcher).

\section{Modern Residential Buildings (Existing Buildings)}

At this stage, specifically in 2002-2003, a comprehensive plan for the city was developed by the Urban Planning Commission for Zuwarah, the total area of the master plan is about 5355.6541 hectares (personal interview with urban planning manager in Zuwarah), and the comprehensive plan for the city became as follows.

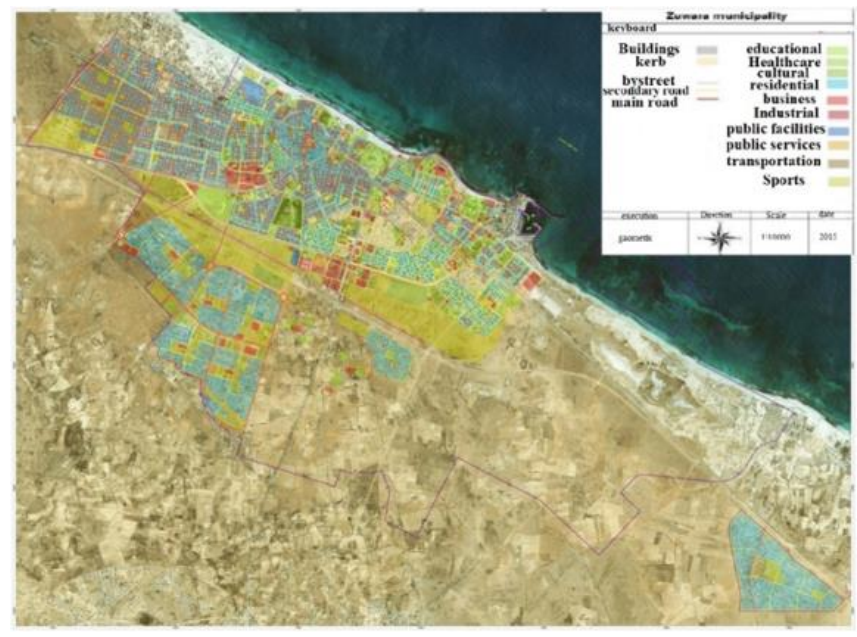

Fig. 11. Zuwarah City Master Plan (personal interview with urban planning manager in Zuwarah).

After the penetration of technology and material philosophy in the science of architecture, the design of the house varied to suit the needs of the contemporary family, as the floor area increased with the change in design methods of interior spaces; Special suites for the bedroom, bathroom, kitchen, living, and guest rooms appeared. Also, the architectural design of facades and projections became more complex. On the other hand, the dominant building pattern (the yard) has disappeared and there is a waste of space [14]. Architectural design and building materials play an important role in the consuming energy. The change that accompanied this stage in the type of building materials and the architectural design that inspired from the Western design without considering the climate difference led to an increase in the amount of electricity consumption [13]. 


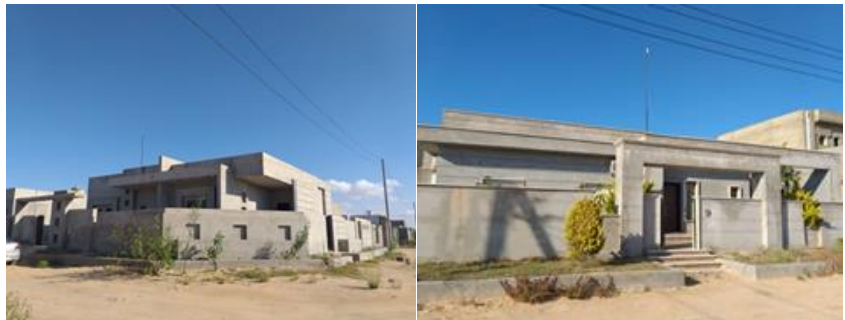

Fig. 12. New residential buildings design (taken by the researcher).

Despite all the economic and social development that has occurred in the city as well as on the residential buildings, the more residential buildings move away from the traditional pattern, the less sustainable they are. Existing houses are more energy depleting from the design until the building completes its life, for example, the disappearance of the inner courtyard, which was moderating the temperature of the house. The building materials (cement) caused air pollution in the production. The cement bricks that were used in the walls did not insulate heat, unlike limestone. Modern residential buildings have become completely dependent on electrical energy to provide thermal comfort (heating, cooling, and lighting) for residents. Thus, most of the current and modern homes are criticized for not taking into account the environmental aspects or economizing in electricity consumption, nor is it concerned with preserving natural resources.

On the other hand, the increased dependence on energy produced from fossil fuels did not give an opportunity to develop sustainable residential buildings, or the passive design using renewable energy in the production of electricity.

Therefore, we need to develop the residential buildings' design to make them more sustainable and dependent on sustainable energy sources to provide energy. This study will analyze the design of a newly built house in Zuwarah and study the possibility of developing it by installing photovoltaic system.

\section{FIRSt CASE StUdy Site}

The case study is located in the western neighborhood with regular planning, so the area of land allocated for construction is almost equal from 440 to 500 square meters per plot, and most of the buildings have one-story and in total they do not exceed two floors and all the newly constructed buildings do not exceed 10 years. And it is considered one of the new urban extensions planned by the city's urban planning administration in the years 2002-2003.

In terms of used building materials, the reinforced concrete used in ceilings, pillars, and plinths; whereas the Cement and sand used in both interior and exterior walls; and all the roofs made of flat-shaped reinforced concrete.

The neighborhood center is about 250 meters from Zuwarah main road. The neighborhood inner roads are sandy roads, with width varies from 15.89 meters to 9.22 meters. The neighborhood is on the same sea level. The following Fig. 13 shows the location of the case study in Zuwarah.

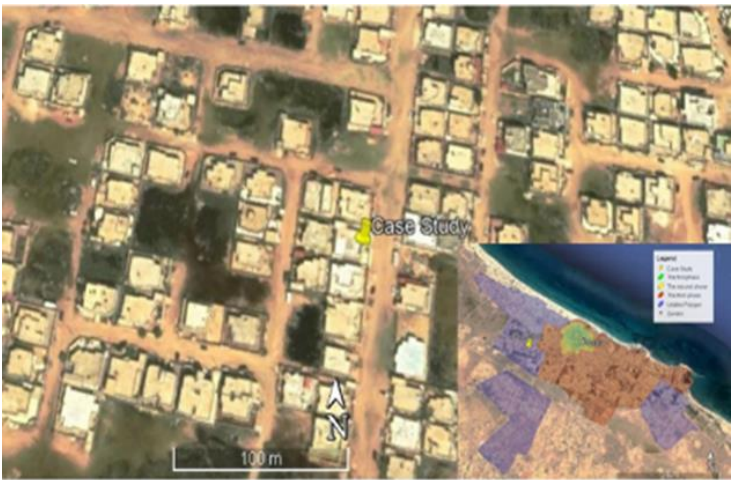

Fig. 13 The location of the case study in Zuwarah (Google maps).

The case study was selected based on the following criteria:

- The location

- This case study contains the spaces that most residents look for in the house.

- The residents of this house are a young family of 5 members, which is the average number of family members in the city.

- The family is from the economically middle class.

\section{A. The Case Study Characteristics}

Our case study is a house built in 2015, facing east-south, it is a one-storey building that has a flat rectangular planetary plan with an area of 250.49 meters, with total height 4.5 meters, ceiling height 3.0 meters, high above the street level 0.6 meters, and the ceiling has a high threshold of 1 meter.

The structure of the building was constructed of reinforced concrete (foundations, columns, and roof) with a thickness of $20 \mathrm{~cm}$. All internal and external walls constructed of hollow concrete blocks; the windows are made of single-layer glass, without any insulation materials in the house.

The interior design of the house divided to suites, where a private suite with 3 bedrooms, living room, kitchen and 2 bathrooms; also, a private suite for the men reception close to the main entrance with reception room and bathroom, with similar suite but for women. The house also has an external balcony on all sides. The following Fig. 14 A, B, 15, 16, 17 describes the case study.

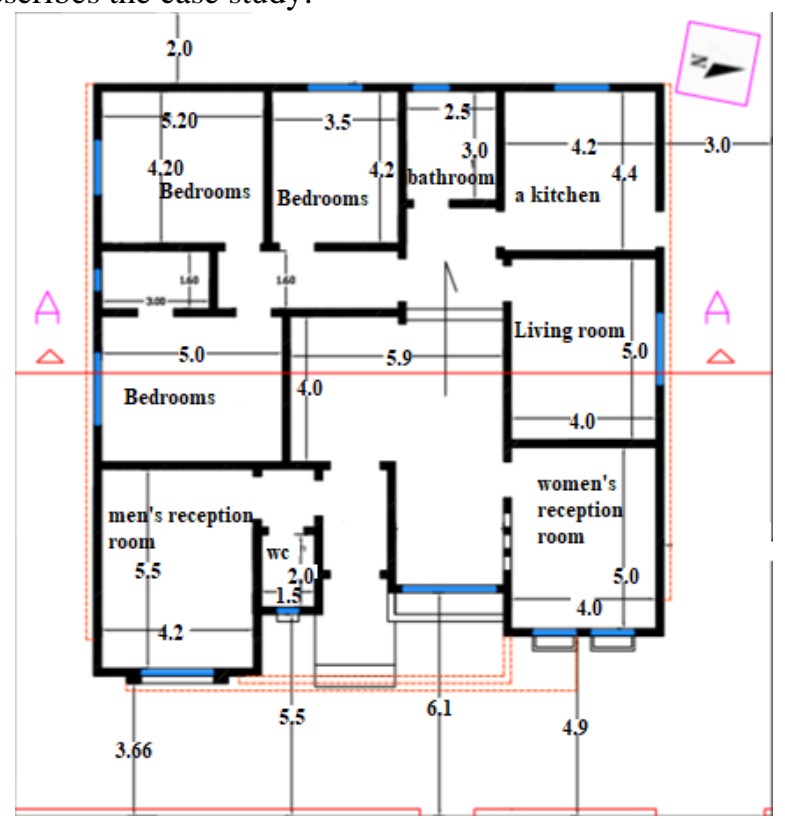

Fig. 14 A. Ground floor plan of the case study1 (done by the researcher). 


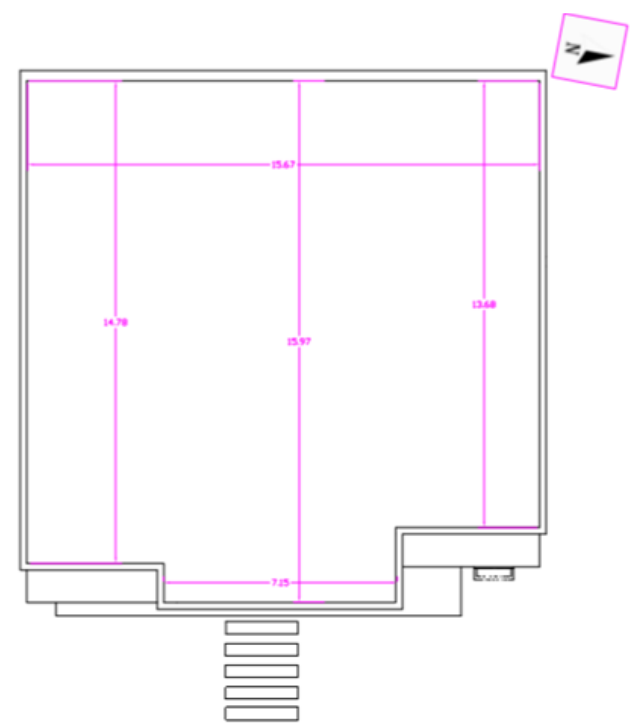

Fig. 14 B. Roof plan of the case study1 (done by the researcher).

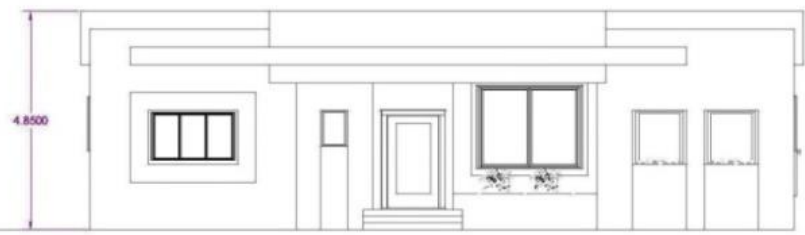

Fig. 15. The main façade of the case study1 (done by the researcher).

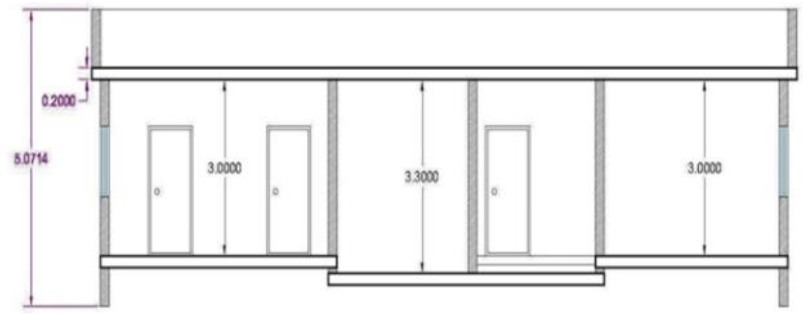

Fig. 16. A-A Section of the case study1 (done by the researcher).

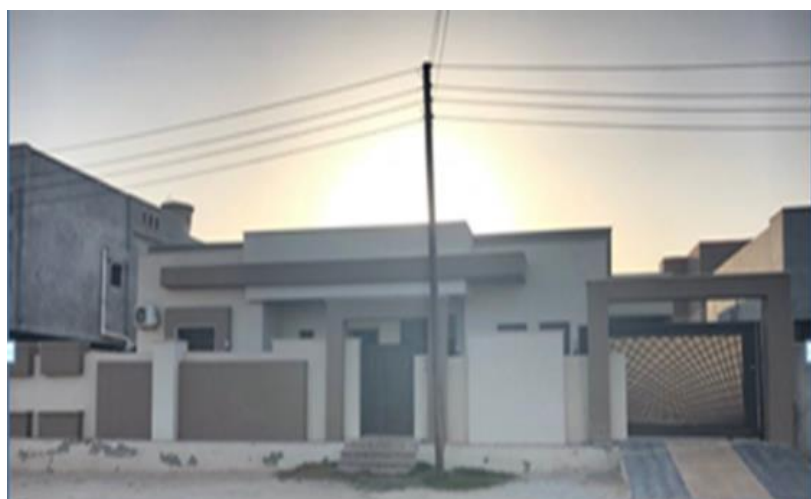

Fig. 17. External photo of the case study (taken by the researcher).

\section{ANALYZE A PV SYSTEM FOR THE FIRST CASE STUDY}

The design of a photovoltaic system in architecture should not affect its energy production. The following factors should be considered: the required amount of energy, the installation angle of the PV modules, shading, and the available space for installation. These factors restrict the integration architecture between building and PV systems [15].

\section{A. The Required Amount of Energy}

Based on the individuals' behavior and the electrical appliances used in homes in general, the household electrical energy consumption was assessed as in the following table.

\begin{tabular}{ccccc}
\multicolumn{5}{c}{ TABLE II: ELECTRICAL ENERGY CONSUMPTION } \\
\hline $\begin{array}{c}\text { Electrical } \\
\text { appliances }\end{array}$ & $\begin{array}{c}\text { number of } \\
\text { appliances }\end{array}$ & $\begin{array}{c}\text { Power } \\
\text { Consumption } \\
\text { by Watts }\end{array}$ & $\begin{array}{c}\text { The } \\
\text { number } \\
\text { of } \\
\text { hours }\end{array}$ & $\begin{array}{c}\text { Total } \\
\text { consumption } \\
\text { by kWh }\end{array}$ \\
\hline $\begin{array}{c}\text { Air } \\
\text { Freezer }\end{array}$ & 1 & 1200 & 6 & 7.200 \\
refrigerator & 1 & 500 & 16 & 8.000 \\
dish washer & 1 & 400 & 16 & 6.400 \\
$\begin{array}{c}\text { Washing } \\
\text { Machine }\end{array}$ & 1 & 1300 & 1 & 1.300 \\
$\begin{array}{c}\text { Bulbs } \\
\text { LEED }\end{array}$ & 8 & 500 & 1 & 0.500 \\
$\begin{array}{c}\text { TV with } \\
\text { receiver }\end{array}$ & 2 & 10 & 6 & 0.480 \\
Electric & 1 & 135 & 3 & 0.810 \\
iron & 1 & 1200 & 0.5 & 0.600 \\
$\begin{array}{c}\text { Charge } \\
\text { Vacuum }\end{array}$ & 4 & 20 & 4 & 0.320 \\
$\begin{array}{c}\text { Cleaner } \\
\text { water pump }\end{array}$ & 1 & 1600 & 0.3 & 4800. \\
\hline & 1 & 1900 & 0.5 & 0.950 \\
\cline { 3 - 5 } & & $\sim 90008765$ & & $\mathrm{kWh} \mathrm{27.040}$ \\
\hline
\end{tabular}

\section{B. The Installation Angle of the PV Modules}

The output of the PV system is greatly influenced by the angle of modules inclination. The most feasible direction in our case study is the south, because of the perpendicularity of the incoming solar radiation with the PV modules at the highest peak, and the modules are exposed to solar radiation more during the day [15]. In order to ensure the efficiency of the system; $21^{\text {st }}$ December is chosen as the shortest day of the year to utilize the system, which has the minimum solar radiation and maximum length of the shadow. The following Fig. 18 shows the sun path during the year at the study site.

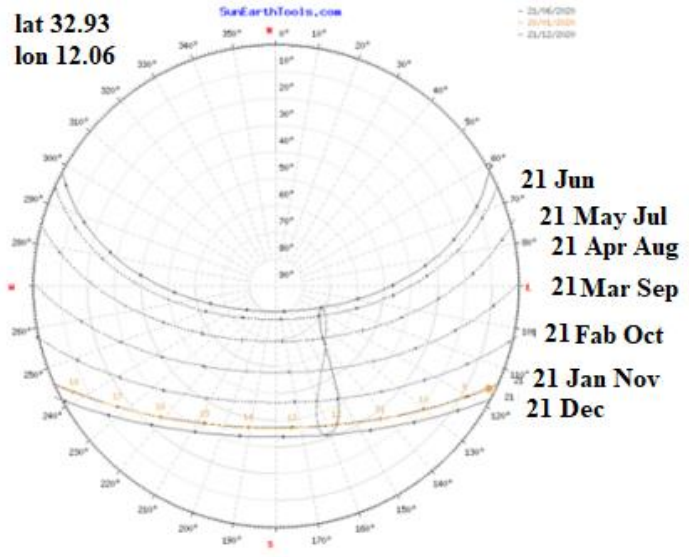

Fig. 18. The sun path during the year at the study site [16]

Also, the optimum angle of inclination varies during the day's hours and the sun position. Therefore, single, or double axis solar tracking system could be used to optimize the PV system production, which accompanied with increasing in the cost and maintenance. Thus, most of PV modules are installed at fixed angles in residential buildings [17]. The Optimum angle of inclination to our case is 32 degrees [18]. The following Fig. 19 shows the sun position during daylight hours on the study case [16]. 


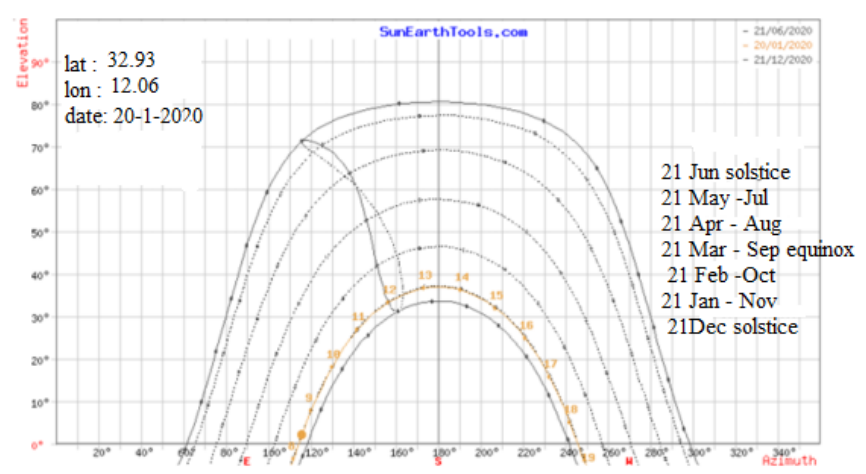

Fig. 19. The sun position during daylight hours on the study case [16].

\section{Shading}

Reducing the solar radiation reaching the PV module because of the shading reduces the current and voltage curve as shown in below figure [19], which in turn affected all the PV system performance. Shading caused by many means such nearby buildings, trees, and the wrong distance among PV modules.

The nearby buildings are one of the most common factors that cause shading on the PV modules site, which prevent the integration of photovoltaic units in the facades. As shown in the case study, where the facades integrations are not possible because the shade of neighboring house far not exceed 4 meters, which considered small according to the building height, so the southern side is shaded during the daylight hours. Based on that, the most optimize place to install PV modules is on the roof and the integration of (ORMPV).

\section{The Available Space for Installation}

The inclined installation of PV modules needs spaces between the rows to avoid the shading problem. To find out if the suitability of surface area to install PV modules, the distance between the PV modules and the number of PV modules required to operate the system have to be calculated:

\section{The distance between the PV modules}

To achieve the maximum performance of the solar system (avoiding shade), as well as the ability to install the required number of panels in the required area. Row spacing or shading distance should be calculated [20]. Based on the following equation and using the 315-SunPower solar panels with a length of 0.986 meters, the angle of inclination 32 degrees, $\mathrm{Y}$ equal to 0.836 meters, and the value of $\mathrm{X}$ is 2.701 meters:

$$
\mathrm{X}=Y \frac{\cos \beta}{\tan \alpha}
$$

where

$\mathrm{X}$ : The distance between the PV modules;

$y:=j(\cos 32)$;

$\beta$ : Azimuth Angle (Degree);

$\alpha$ : Solar Altitude at Certain Solar Time (Degree).

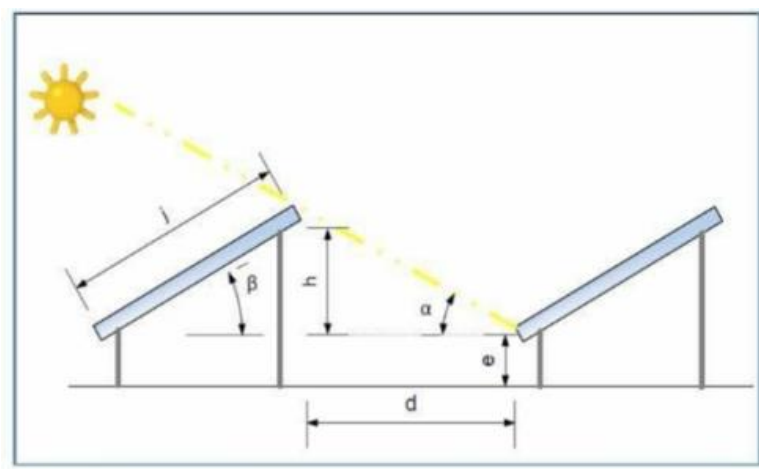

Fig. 20. Calculating the distance between the PV modules [20].

\section{Number of required $P V$ modules}

Number of required PV modules are depending on the unit capacity, the required energy to operate the load, the energy loss factor in the system (generally 1.3) [21]. Panel Generation Factor (PVOUT) which set at $4.753 \mathrm{kWh} /$ day for the study site [22].

After determining the previous requirements, the number of required PV modules can be determined as following [21].

- The total energy required to operate the system $=$ the required energy to operate the load* the energy loss factor.

$$
27040 \times 1.3=35152 \mathrm{wh} / \text { day }
$$

- The total peak watt required to operate the load $=$ The total energy required to operate the system / Panel Generation Factor (PVOUT).

$$
35152 / 4.75=7400.42 \mathrm{Wp}
$$

- Number of required PV modules= total peak watt required to operate the load/ capacity of the specified PV modules.

$$
7400.42 / 300=26 \mathrm{PV} \text { modules }
$$

\section{Design A PV System FOR THE FIRST CASE STUdy}

After identifying all the factors affecting the design of a PV system for a chosen residential home. The PV system can be designed using the simulation program (PVsyst) to study the system efficiency.

PVsyst is a program to simulate the PV systems, enabling detailed analyze and design for grid-connected PV systems, off-grid PV systems and Solar powered irrigation systems [23].

The system design procedure using the program goes through several steps:

- Determine the case location, latitude (32.83 degrees) and longitude (12.06 degrees). Metro data uploaded by the software from its server upon providing the location details.

- Define the tilt angle of the panel, from the "orientation" option in the main page. The software can optimize the tilt angle according to the sun curve, tilt angle is set to $32^{\circ}$.

- The load demand from Table I uploaded into the software, through "system" option in the main page. 
The operation period of the specific load throughout the day can be also defined from this page.

- Determine the PV batteries configurations and inverter, which set as LG electronics.

The program will automatically determine the number of required panels, batteries, and the power of the inverter according to the entries. After designing the PV system using the pvsyst program, the PV modules can be installed on the roof of the study sample to verify its integration with it.

\section{Designing Methods For InTEGRATING PV Modules ON THE HOUSE ROOF}

The integration of PV systems on the roof (ORMPV) is the most attractive type, because the roof occupies largest area exposed to solar radiation, without shading, as opposed to integration with facades.

PV modules can be integrated in different methods. The researcher used a sketch program to illustrate methods of integrating PV modules with the roof in the case study.

A. Distributing the PV Modules on the Ceiling in an Open Stacking Style, with Successive Orientation and Tilt (the Optimum Angle)

In this method, the PV modules are distributed on the roof in successive rows, with 2.701 meters distance between rows, and 1.5 meters safety distance around the wall. The system installed in four consecutive rows as shown in the following figure. The method advantages are not affecting the exterior of the house, acting as a thermal insulation by reducing the arrival solar radiation to the roof. While the disadvantage is not using the roof normally.

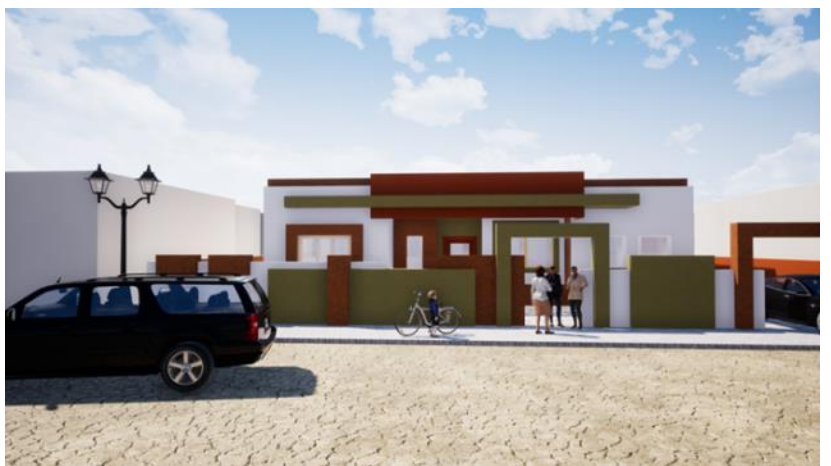

Fig. 21. The visual effect of solar panels on the facades (developed by researcher).

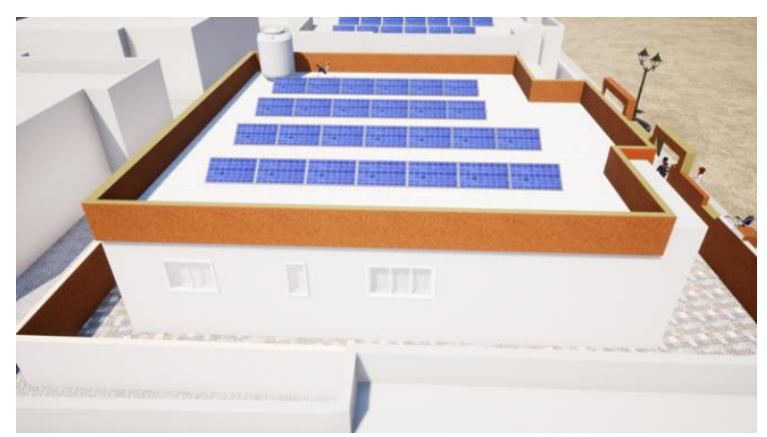

Fig. 22. Distributing the modules on the roof (developed by researcher).

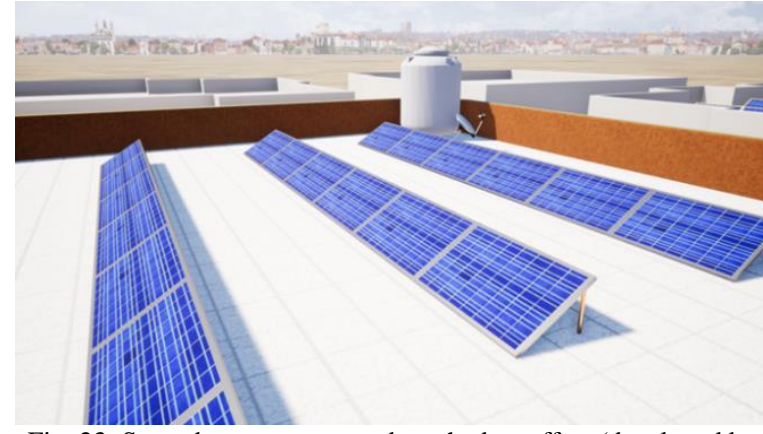

Fig. 23. Space between rows and no shadow effect (developed by researcher).

B. Distributing the PV Modules on the Roof in a Close Stacking Style, with Successive Orientation and Tilt (the Optimum Angle)

In this method, the panels are grouped vertically on each other with fixed angle inclination and successive orientation as shown in the following figures. The method advantages are using the rest of the roof normally, and the other components of the system can be placed under the shaded part. While the disadvantages are the modules vulnerability to the winds and affecting the building exterior.

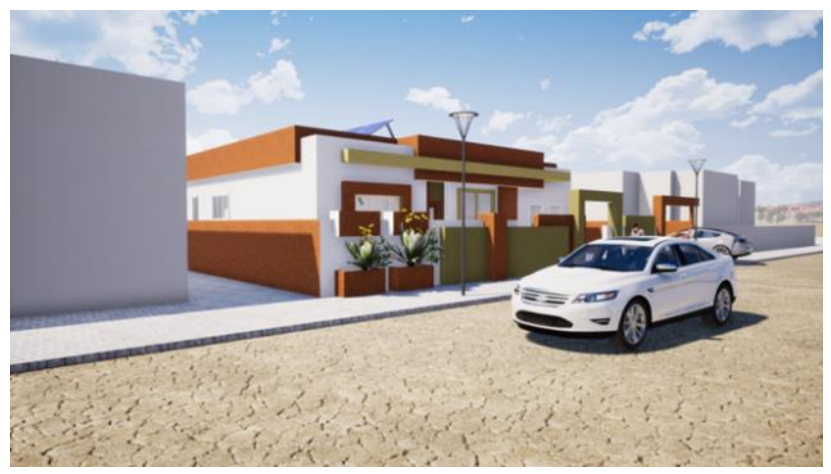

Fig. 24. The visual effect of solar panels on the facades (the researcher using sketch).

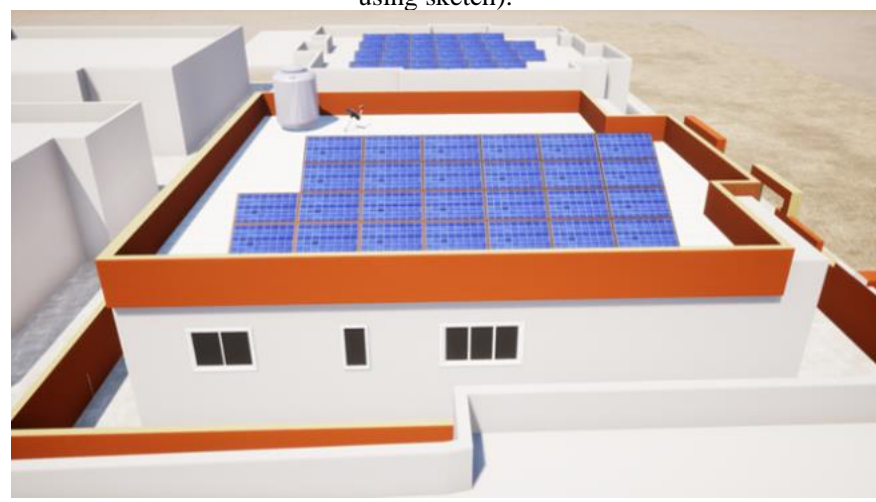

Fig. 25. Distributing the modules (developed by researcher).

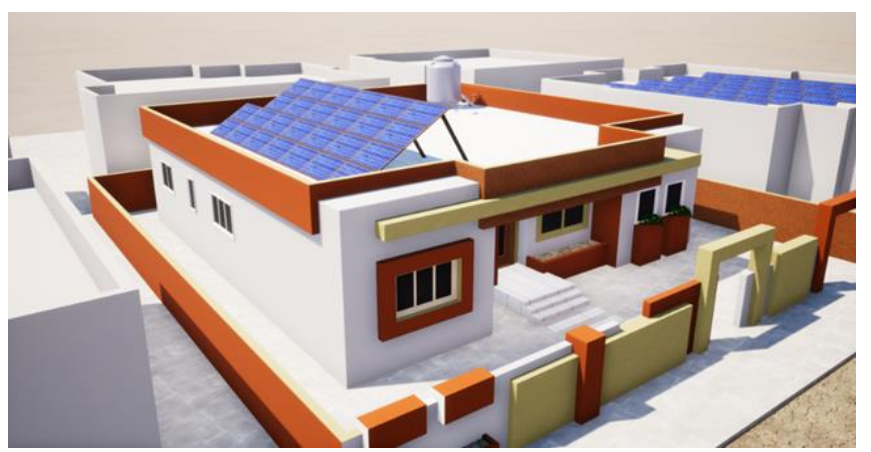

Fig. 26. The free space on the roof (developed by researcher). 
C. Distributing the PV Modules as a Canopy on the Roof, with Successive Orientation and Tilt (the Optimum Angle)

In this method the PV modules installed as a canopy on the roof. The researcher designed a canopy over the roof tilted at an angle of 32 degrees and directed towards the south using solar panels and woods as shown in the following figures, to be used as shaded sitting places, with the ability to use the rest of the roof. The increased cost comparing with the other methods is the disadvantage of this method.

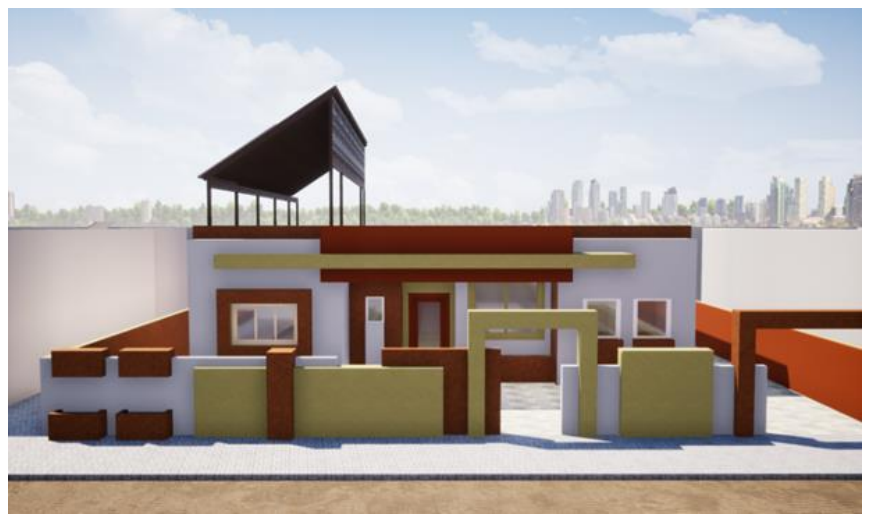

Fig. 27. The canopy in the front face (the researcher using sketch).

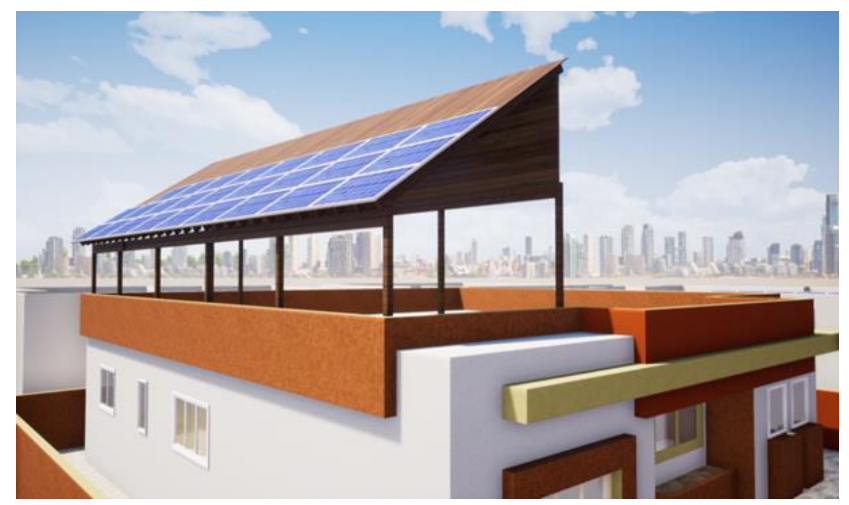

Fig. 28. Canopy design method (developed by researcher).

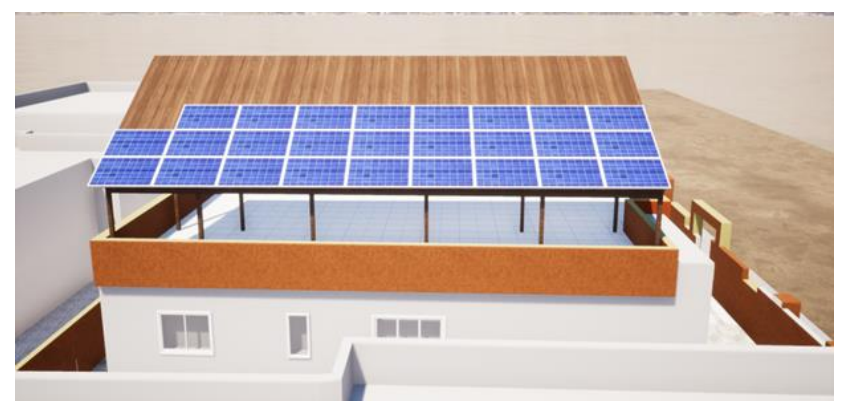

Fig. 29. Panel distribution methods (developed by researcher).

\section{SeCond CASE Study}

The second case study is a residential neighborhood located in the northeastern side of the city, close to the sea, on two vertical roads, as shown in the following map. The site height about 2 to 3 meters above sea level (Gogol Earth).

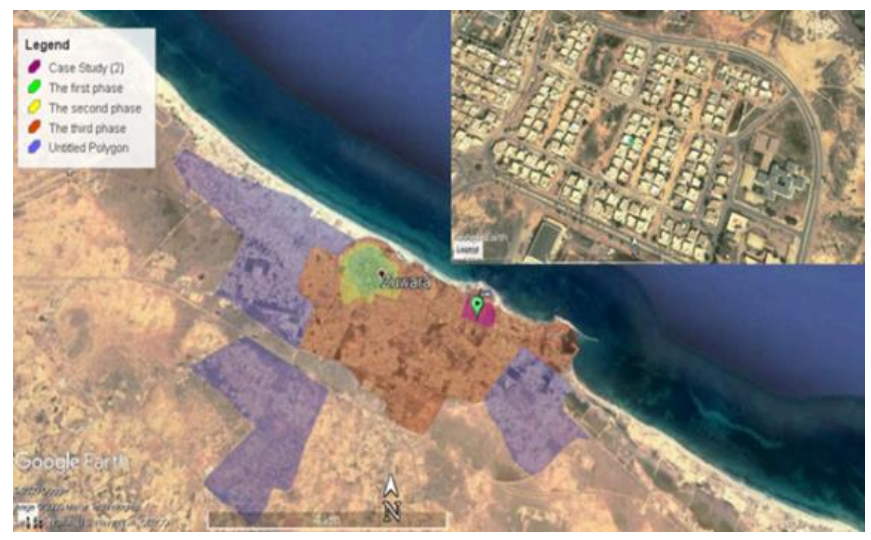

Fig. 30. The second case study site (Gogol Earth).

The case study is one of the government projects started in the eighties by contracting with the Turkish Union Companies for Construction and Trade, which developed a design for a Greek company to the neighborhood. This project contains 300 houses with two-floors distributed on the site regularly in different directions. Completed and delivered to citizens in the mid-nineties after terminating the contract with the Turkish company and handling it to the savings bank.

The site design is considering regular, with designated areas for gardens, which not implemented yet. The site is surrounded by paved roads linking it to the rest of the city, while most of the internal roads are paved and others are not yet; the width of them ranges from 17 to 21 meters (Gogol Earth).

The site was chosen because it contains a large number of units with two-floors, which provide the chance to integrate the solar panels in the facades. The neighborhood needs to be renewed, as the buildings no longer have a unified architectural character, as shown in the following Fig. 31-34.

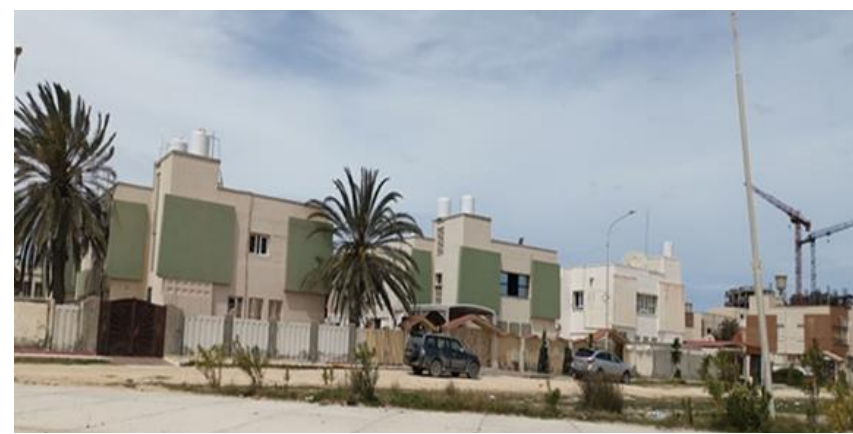

Fig. 31. The facades shape (taken by the researcher).

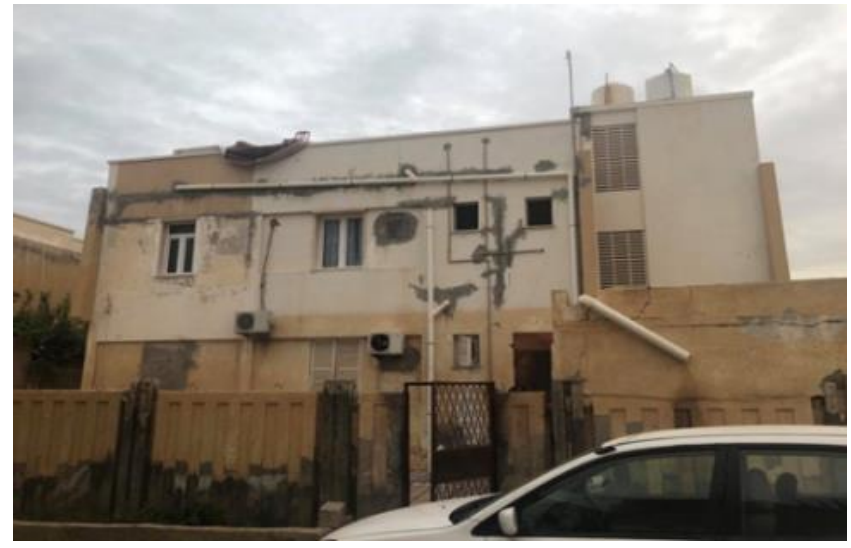

Fig. 32. Modernized facades (taken by the researcher). 


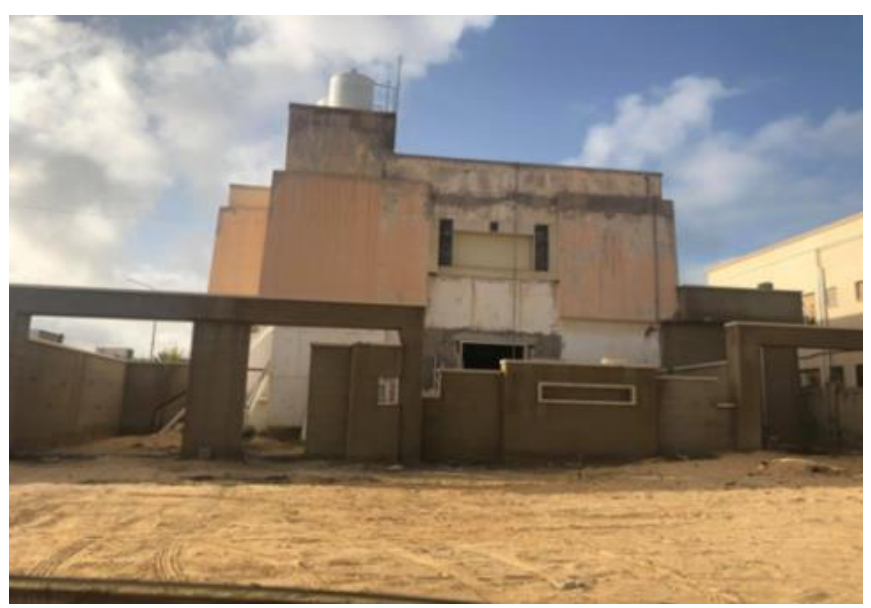

Fig. 33. Changed facades (taken by the researcher).

In the following figure, the ground floor was maintained, while the first floor remained without repair, which result asymmetry in the exterior of the building.

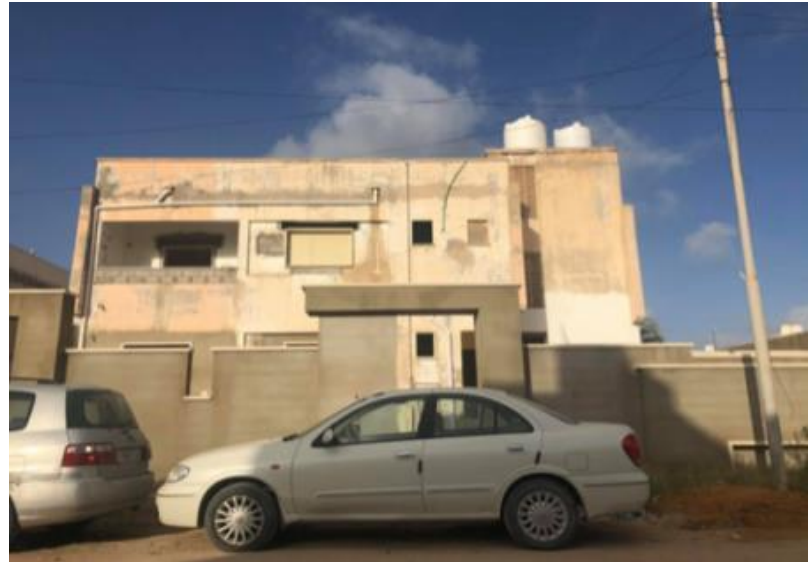

Fig. 34. Changed facades and lack of restoration (taken by the researcher).

\section{A. The Second Case Study Characteristics}

The second case study is a residential neighborhood with two-story buildings that have a horizontal square plan with a flat surface, the roofed area of one building is 371.66 meters, and their total height is 11.5 meters. The inner and outer walls are hollow concrete blocks of dimensions $20 \mathrm{~cm}$ thick, $20 \mathrm{~cm}$ high and $40 \mathrm{~cm}$ wide. As for the windowsills, they are made of single-layer glass. The muddy foundation was also used because of the type of soil (sabkha). In addition, its façades contain large concrete blocks.

The interior design of the house divided to 3 rooms, reception hall, store, bathroom, kitchen, and the entrances to the apartments in one building are separates. The following figures are illustrating the architectural design of the buildings.

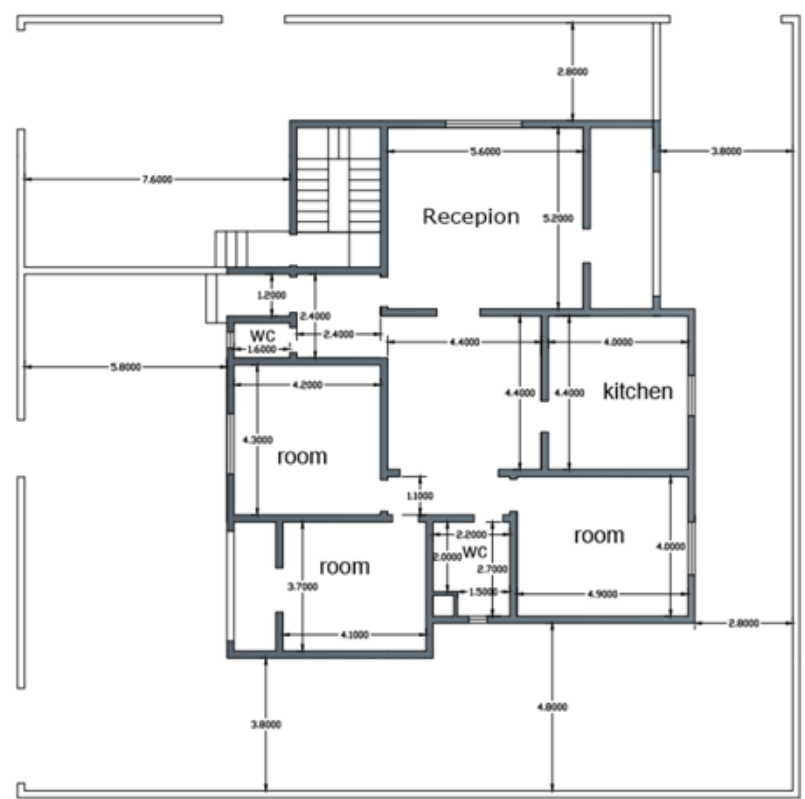

Fig. 35. Ground floor plan of the case study 2 (done by the researcher)

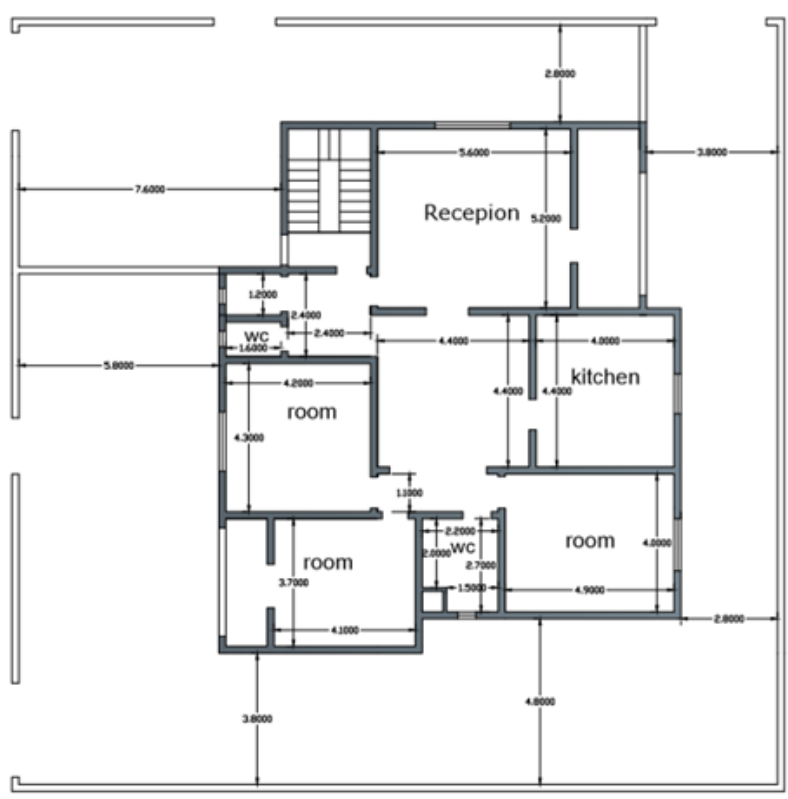

Fig. 36. First floor plan of the case study 2 (done by the researcher).

\section{INTEGRATION OF PV SYSTEM WITH THE SECOND CASE STUDY}

In addition to the energy produced through integrating the PV system with the buildings, it is adding a contemporary architectural character, through introducing changes to the architectural image of the building, without affecting the visual presence of the major blocks in the design. This level of integration can be employed in previously constructed buildings that lost the renewal character over time, as a dominant part of the general appearance defining the character of the architectural work. And usually used with large areas to increase the energy efficiency of the building.

The two-story buildings in the case study, motivated the researcher to renew the facades and develop them architecturally through encapsulating prominent blocks in the facades with PV modules instead of traditional methods in cladding such graphite, marble, or natural stone. Which in turn saving energy and increasing the attractiveness of the 
building. The following 3D figures are illustrating methods of integrating facades with PV modules.

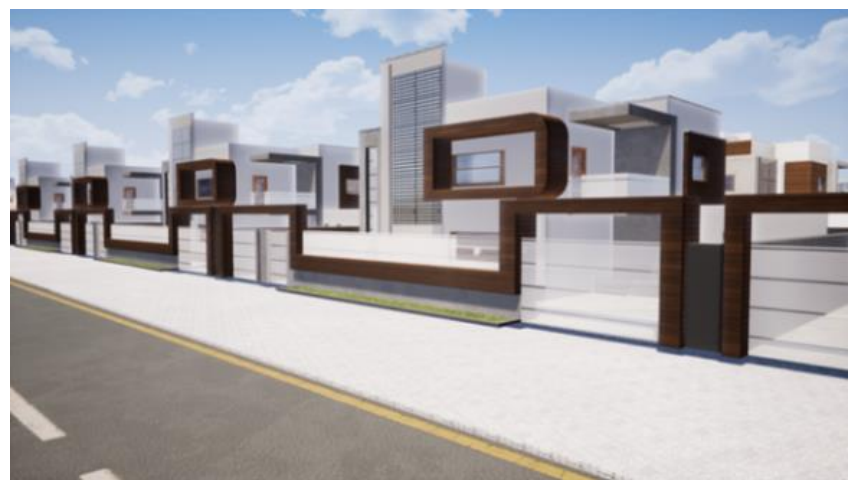

Fig. 37. Facade development and standardization through integration with PV modules (developed by researcher).

The Integrated PV modules with building facades are being more obvious than other types of integration. Large areas of facades can be invested to generate energy as in our case.

However, the facades side and the inclination angle of PV modules are affecting the amount of produced energy as sometimes the facades are shaded for longer periods comparing with other surfaces. Where the PV systems efficiency depends on the amount of the valuable and available surface area of the facades. Therefore, the researcher has tried many orientations and installments for the PV modules on the facades to obtain the largest amount of solar radiation, as shown in the following Fig. 38-41.

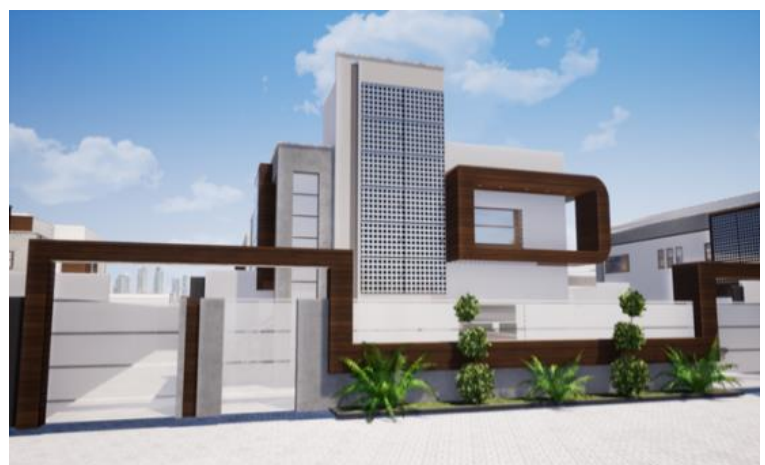

Fig. 38. The first integration of facades with PV modules (developed by researcher).

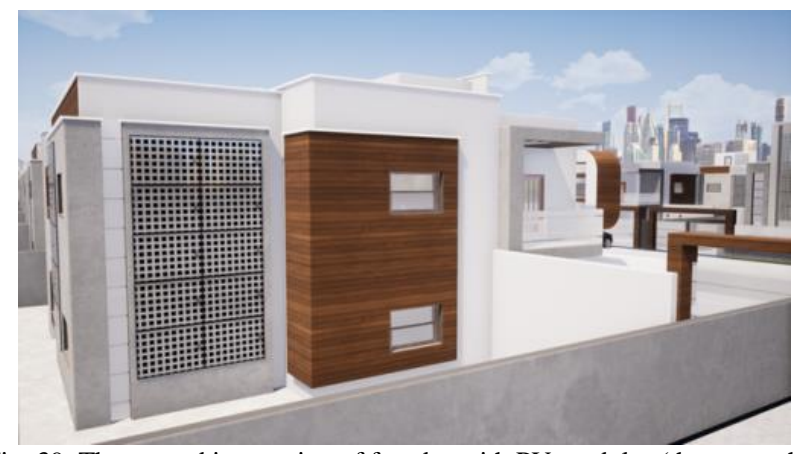

Fig. 39. The second integration of facades with PV modules (the researcher using sketch).



Fig. 40. The third integration of facades with PV modules (the researcher using sketch).

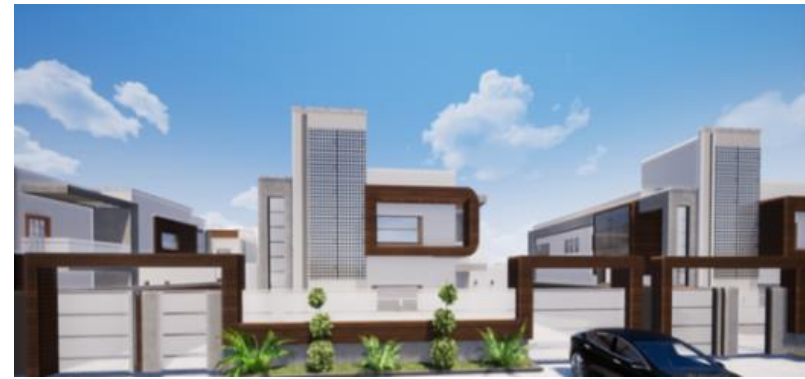

Fig. 41. The fourth integration of facades with PV modules developed by researcher).

It is good to mention that the production of the PV system in the first case study is more than the second one, due to the optimal orientation and inclination angle. However, in the second case study the integration had functional role represented by providing energy, and architectural role.

\section{ENVIRONMENTAL FEASIBILITY OF THE PV SYSTEM}

The most important positive aspects of solar energy projects are the environmental impacts through reducing the use of fossil fuels, which in turn reducing the toxic gas emissions.

The researcher will compare the Environmental effects of PV system comparing with a diesel generator (the fuel consumption of the diesel generator depends on the type, size, and capacity of the generator, as well as the amount of load attached to it).

According to the [24] study a diesel generator with $15 \mathrm{KW}$ power burns 6 liters of diesel per $\mathrm{kWh}$, whereas burning one liter of diesel produces $2.6 \mathrm{~kg}$ of carbon dioxide gas [15]. I.e., using the generator 6 hours daily, burning about 36 liters of diesel, which release of approximately $93.6 \mathrm{~kg}$ of carbon dioxide, in return, the production of the same amount of energy by the PV system is completely free $\mathrm{CO}_{2}$ gas.

In addition, PV system emits approximately $50 \mathrm{~dB}$ noise through the invertor, while the diesel generator emits up to $120 \mathrm{~dB}$ [15]. On the other hand, placing the modules on the building roof reduces the sun radiation and thus contributes to lowering the house temperature.

\section{ECONOMIC FEASIBILITY OF THE PV SYSTEM}

Based on the [24] study, which compared between diesel generator and PV system with $15 \mathrm{KW}$ power:

Economic cost of the generator: 
- The daily consumption of a generator that works 6 hours is 36 liters daily.

- Annual maintenance, estimated at 700 Libyan dinars.

- The average diesel consumption is 262800 Libyan dinars annually.

- The estimated age is about 8 years.

- The average price is 52,000 Libyan dinars.

- The total expenses for 8 years using is 320400 Libyan dinars.

- The economic cost of the solar system.

- The estimated age is about 25 years.

- The average price is 67,551 Libyan dinars.

Based on this study, it is clear that the economic viability of solar systems is higher than generators. In addition to reduce the load on the public electricity grid, which contribute to raise the country's economy.

\section{CONCLUSION}

The study clarified that PV systems are suitable for forming sustainable architectural through their ability to achieve its principles and integration with existing buildings. Also, the study discussed the ability utilize PV systems in Libya to achieve sustainable integration with the existing buildings. The following results have been obtained.

1. The geographical location of Zuwarah city helps to produce highly efficient solar energy.

2 . The changes in the design and building materials in residential buildings, had a negative impact on the thermal comfort of the building and affected the building's energy consumption.

3. Most of the existing buildings are not energy efficient, and there are no standards or guidelines for designing energyefficient buildings that are compatible with the climate of Zuwarah.

4. PV modules can be integrated with existing buildings in Zuwarah city in different ways.

5. All the roofs in the city are flat without shading areas, which make them the optimal place for installing PV systems, to produce solar energy and reduce the building temperature resulted from the from solar radiation.

6. PV modules can be used to renew the existing residential buildings, as they can be integrated with the building façades and replace the external cladding materials.

7. The designer has to obtain the optimal direction for PV modules to produce the maximum energy. However, the design is a flexible process, and sometimes increasing the aesthetic and economic value of the building is more valuable than energy producing, while the functional multiplicity of PV modules will help compensate for the decrease in efficiency.

8. Economically and environmentally PV system are more feasible than the fossil energy, despite its high initial cost. Therefore, it is one of the simplest solutions that can help solve the energy problem in Libya in general and the city of Zuwarah in particular.

\section{REFERENCES}

[1] Bagher, A. M., Vahid, M. M. A., \& Mohsen, M. Types of solar cells and application. American Journal of optics and Photonics, 2015, 3(5), 94.

[2] Atwah M, Abdulrahman $\mathrm{H}$ \& el Aomre H, Preferred Methods for Incorporating Photovoltaic Cells into the Roofs of Buildings An Analytical Study of Buildings of Popular Housing in Qena City, Journal Of Al Azhar University Engineering Secto, 2017.

[3] Gussenhoven, C. Zwara (Zuwārah) Berber. International Phonetic Association. Journal of the International Phonetic Association, 2018, 48(3), 371-387.

[4] Helmy Y. Zuwara memory. soon published.

[5] Ahmed, A \& Zayed, M. The origin and formation of coastal sabkhas in western Libya. Academic Research Journal - Ninth Issue. 2019. P 237. 347.

[6] Center for Scientific Curricula and Educational Research. Libya Geography, A specialized committee commissioned by the Center for Educational Curricula and Educational Pure, 2020.

[7] Environment Public Authority. Fourth National Report on Implementation of Biodiversity Agreements, 2010, pp. 16-27.

[8] Baggas, N,Climate northwest of Libya A study in climate geography, $\mathrm{PhD}$ thesis in the Department of Geography, Faculty of Arts, Ain Sh University,2015,P-56_60_62.

[9] Asswani S,Solar Power in Libya, Journal of Faculties of Education, 2019, No. 14. p. 273

[10] Poliservice. Zuwara Comprehensive Report No. N-5, Engineering Consultation, Municipal Projects Office, Vadiko Warser - Poland Office, 2000.

[11] Awad, A \& Ibrik, H,The sustainability of the Libyan coastal housing, 2017.

[12] Sasi, E., \& Harputlugil, G. U. Exploring Problematic Issues of Housing Design in Hot Humid Climate: Libyan Case. GRID-Mimarlık Planlama ve Tasarım Dergisi, 2019, 2(1), 1-24.

[13] Kahil,F.The emergence of electric energy in Libya and its development with application to the northwest region of Libya, Faculty of Arts / AlAsmarya University,a study of energy geography 2018. https://jssa.journals.ekb.eg/article_29869_8466e115e01bb7e3c721c6e 3896f8835.pdf.

[14] Mabrouk, A. Hassan, A. Ahmed,K. Al-Azizi, M,The impact of changing the needs of Libyan family on the design of the modern private residence. Journal of Engineering Sciences Assiut University Faculty of Engineering, 2017, Vol. 45 No. 2, PP. $244-266$.

[15] Abdul Razzaq A, Ahmed A,Photoelectric system design for a virtual Iraqi house, Researchgate, 2018, 2.2.29487.59048.10.13140.

[16] sunearthtools.com.

[17] Asif M , Hassanain M , Nahiduzzaman K and Sawalha H Technoeconomic assessment of application of solar PV in building sector A case study from Saudi Arabia, Emerald insight, 2019.

[18] Yadav, A. K., \& Chandel, S. S. Formulation of new correlations in terms of extraterrestrial radiation by optimization of tilt angle for installation of solar photovoltaic systems for maximum power generation: case study of 26 cities in India. Sādhanā, 2018, 43(6), 1-15.

[19] Fathy A, Recent meta-heuristic grasshopper optimization algorithm for optimal reconfiguration of partially shaded PV array, Science Direct, Solar Energy, 2018, Volume 171, Pages 638-651.

[20] Al-Najideen M \& Alrwashdeh S, Design of a solar photovoltaic system to cover the electricity demand for the faculty of Engineering- Mu'tah University in Jordan, Science Direct, Resource-Efficient Technologies, 2017, Volume 3, Pages 445-450.

[21] Ndagijimana, Tech $M, \&$ Kunjithapathan $b$, Design and Implementation PV Energy System for Electrification Rural Areas, International Journal of Engineering and Advanced Technology (IJEAT), 2019, Volume-8 Issue-5, ISSN: 2249-8958

[22] (globalsolaratlas.info)

[23] Haydaroğlu C, Gümüş B, Simulation of Dicle University solar power plant with PVsyst and evaluation of performance parameters, Dicle University Engineering, 2016, Volume 7, Pages 491-500.

[24] Al-Ghanoudi N, Photovoltaics against generator, $20 \mathrm{hp} \mathrm{pump,}$ Workshop on the impact of the energy crisis on the industrial sector and its treatment (problem, solutions and response) 2020. 